\section{Vladimir Lončarević}

Hrvatsko katoličko sveučilište

u Zagrebu

vladimir.loncarevic@zg.t-com.hr
Data przesłania tekstu do redakcji: 18.03.2015

Data przyjęcia tekstu do druku: 09.05.2015

\title{
Je li hrvatski književni modernizam bio antikatolički usmjeren? Jedan idejni vidik polemike između ,starih" i ,mladih" u hrvatskoj književnosti na prijelazu između 19. i 20. st.
}

\begin{abstract}
Lončarević Vladimir, Je li hrvatski književni modernizam bio antikatolički usmjeren? Jedan idejni vidik polemike između ,starih" $i$,,mladih” u hrvatskoj književnosti na prijelazu između 19. i 20. st. (Was Croatian Literary Modernism Anti-Catholic? One Conceptual Aspect of the Dispute Between "the Old" and "the Young" in Croatian Literature at the End of the $19^{\text {th }}$ and the Beginning of the $20^{\text {th }}$ Century). "Poznańskie Studia Slawistyczne" 10. Poznań 2016. Publishing House of the Poznan Society for the Advancement of the Arts and Sciences, pp. 297-311 . ISSN 2084-3011.

An interesting conceptual dispute, usually called a confrontation between "the old" and "the young", developed at the end of the $19^{\text {th }}$ and the beginning of the $20^{\text {th }}$ century. Although by its name defined as a "clash of generations", the dispute was basically rooted in differences between two groups of writers concerning their attitudes toward arts: of traditionalists, whose starting point was the principle of the unity of truth, beauty and good, and of modernists, who relied on aestheticism and concept of l'art pour l'art'. "The young", while upholding individualism, particularly used to stress their anti-Catholicism. The author checks whether at their root there was anti-Catholicism. He comes to the conclusion that Croatian Moderna was not an organised anti-Christian or anti-Chatolic movement, even though it isn't doubtful that anticlericalism of "the young", to a large degree, assumed contours of antagonism towards public expression of Catholicism in culture, harbingering at the same time secularist conceptual processes that were expressed later in the political field and all the other fields of social life.
\end{abstract}

KeYwords: Croatian Moderna; dispute between "the old" and "the young"; anticlericalism; anti-Catholicism 


\section{Uvod}

Hrvatska se književnost u velikoj mjeri razvijala na istoj duhovnoj bazi i u ritmu promjene stilskih formacija kao i većina europskih nacionalnih književnosti, no imala je svoje idejno-razvojne posebnosti. Prije svega mislimo na tematski korpus tzv. antiturcica između kraja 15. i kraja 19. st. te na političkopreporodnu književnost tridesetih i četrdesetih godina 19. st. Osim toga, posebnost je njezina razvoja donekle zakašnjela „modernizacija" u odnosu na većinu nacionalnih književnosti zapadnog uljudbenog kruga. Naime, sve do smrti Augusta Šenoe, do početka osamdesetih godina 19. st., hrvatska je književnost bila eksplicitno ili implicitno prožeta kršćanskim svjetonazorom ${ }^{1}$, dakle dulje nego što je to bilo u većini nacionalnih književnosti zapadnog kruga, kojem hrvatska književnost nedvojbeno pripada, premda ni utjecaj ruske književnosti 19. st. na nju nije bio zanemariv.

Ta okašnjelost modernizma ima razlog, osim u specifičnim političkim prilikama i zadaćama hrvatske književnosti, i u snažnoj ukorijenjenosti hrvatskih književnika u katoličko kršćanski duhovni kod, koji je često čvrsto sljubljen s domoljubnom ulogom književnosti. Poljski kroatist Marian Zdziechowski svojedobno je u polemici s Vatroslavom Jagićem istaknuo prvake hrvatskoga romantizma Ivana Mažuranića i neoklasicizma Petra Preradovića kao one koji su, spojivši misao o domovini s religioznim čeznućem za kraljevstvom Božje istine na zemlji, stavili pjesništvo u sferu teocentrizma (cf. Zdziechowski 1903: 102, 1). No elementi i sadržaji kršćanske vjere tijekom toga razdoblja prisutni su gotovo u svih pisaca. Njihova formalno-stilska inovativnost i idejna tendencioznost nije ih odvojila od tradicije niti su je oni diskontinuirali.

Religioznost i religiozno kršćanskoga, točnije - katoličkoga identiteta skladno dakle funkcionira u sklopu socijalnih i političkih angažmana naših pisaca. Međutim osamdesetih i početkom devedesetih godina 19. st. mladi pisci - Silvije Strahimir Kranjčević, Ante Kovačić, Eugen Kumičić, Josip Kozarac, Antun Gustav Matoš, Ksaver Šandor Gjalski, Vjenceslav Novak

${ }^{1}$ Književni kritičar i povjesničar Božidar Petrač ističe da se čitavom hrvatskom književnošću, i srednjovjekovnom, i onom od Marka Marulića do početka 20. st. ,eksplicitno ili implicitno, neposredno ili posredno, u različitim stilskim formacijama, protežu (...) biblijske teme, kršćansko, katoličko pojmovlje i kršćanstvu vlastite vrijednosti” (Petrač 1995: 79). 
- sve snažnije upućuju hrvatsku književnost na recentne europske stilsko-formalne, ali i sadržajno-tematske i idejno-svjetonazorske modernističke trendove. Zdziechowski podsjeća na nove duhovne struje koje se iskazuju „u borbi teocentričnog nazora o svijetu sa antropocentričnim t. j. da li je ciljem čovjeka Bog a njegovom dužnošću ispunjavanje zakona Božjeg - ili da li je čovjek najviše biće u svemiru i da je sam sebi cilj" (Zdziechowski 1903: 102, 1).

Iako zbog toga na književnoj sceni, unatoč povremenim polemičkim istupima, nema nikakvih radikalnih sukoba, duhovni nemiri i vjerske sumnje sve se snažnije osjećaju. Beletristika spomenutih i drugih mlađih pisaca daje naslutiti prijelom koji će nastati. U poeziji taj navještaj daje Kranjčević svojim pjesništvom skepse i pesimizma. U proznom pak stvaralaštvu crno-bijela aksiologijska šablona istrošila se. Junaci postaju antijunaci. To se događa već s Ivicom Kičmanovićem u Kovačićevu romanu U registraturi (1888), koji tematizira duševne lomove pojedinca u društvenim preobrazbama druge polovice 19. st., završivši u ludilu. Novakov Pavao Šegota u istoimenom romanu (1888) počini samoubojstvo, a Tito Dorčić u istoimenu romanu (1906) poludi od grižnje savjesti. Leskovarov junak Đuro Martić u pripovijetci Misao na vječnost (1891), možda prvoj modernističkoj pripovijetci ${ }^{2}$, također će poludjeti. Leskovarovi su muški likovi uopće tipični „modernisti” - neodlučni melankolici, primjerice Pavao Petrović u Propalim dvorima (1898) i Marcel Bušinski u Sjenama ljubavi (1899). Radmilović (1894) Ksavera Šandora Gjalskoga u istoimenu romanu poludi zbog neshvaćanja sredine u kojoj živi. I najpoznatiji romaneskni junak moderne Đuro Andrijašević u romanu Bijeg (1909) Milutina Cihlara Nehajeva poludi i ubije se, ,izrazivši tako unutranji slom čitavog ovog pokoljenja” (Maraković 1943: 643). Đuka Begović Ivana Kozarca (1911) i Kamovljev autobiografski roman Isušena kaljuža (napisan 1909, objavljen 1957) moralno i duhovno daju bliskoznačne antijunake melankolije, skepse, eskapizma, nihilizma, apsurda i kaosa.

Taj tipsko-figuralni dijapazon antijunaka „slobodnog morala” i ,slobodne misli" upućuje na napukline mladoga naraštaja hrvatskih pisaca

${ }^{2}$ Cf. Šicel 2002: 81. Ivo Frangeš misli da je Leskovar bio najpotpuniji modernist (Frangeš 1987: 230). Cvjetko Milanja smatra ga ,začetnikom književne prakse moderne” (Milanja 1987: 22). Već je Milan Marjanović držao da „Leskovar markira prijelaz izmedju realizma i modernizma" (Marjanović 1902: 178). 
u pristupu tradicijskoj moralno-vjerskoj ulozi pisca, što indicira idejnu, a ne stilsko-formalnu raspuklinu među hrvatskim književnicima ${ }^{3}$, koja će otvoreno nastati potkraj 1898. u povodu otvorenja Hrvatskog salona u Zagrebu.

Kada se dakle ustvrdi da „krajem devetnaestog stoljeća u hrvatskoj kulturi dolazi do prekretnice” (Flaker 1977: 7) ili „o previranjima koja iskazuju stanje duha, nov pogled na kulturu" (Žmegač 2001: 18) ${ }^{4}$, onda se istinitost tih konstatacija može provjeriti u spomenutim i drugim primjerima hrvatske književnosti toga doba. Pa ako već hrvatska književna povjesnica treba da odista prihvati ikakvu djelidbu hrvatske književnosti na „stariju” i „noviju”, onda ju je opravdano načiniti ne u vrijeme ilirizma, već u vrijeme na prijelazu između realizma i moderne, koja ne znači samo novu „stilsku formaciju”, kako je književne epohe opojmovio Aleksandar Flaker, već i novu ,idejno-duhovnu formaciju”.

\section{Secesijski casus belli}

Genezu prijepora i sukoba na književnoj sceni valja dakle tražiti prije svega u novim idejnim strujanjima u tadašnjoj hrvatskoj kulturi. U analizama općih duhovnih previranja s kraja 19. i početka 20. st. hrvatski filozofi,

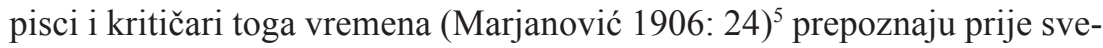
ga Nietzscheovu filozofiju kao osnovicu modernizma - posebice isticanje individualizma (cf. Ujević 1933: 32-34. O tome i Hinković 1902: 13) modernizma više kao svjetonazora nego kao zaokruženog filozofijskoga sustava. I kasniji hrvatski analitičari književnih kretanja gotovo redovito ističu da je „Nietzsche bio u znatnoj mjeri otac «moderne»"

${ }^{3}$ Povjesničar hrvatske moderne Miroslav Šicel piše da ,p o k r e t nije imao, kao što je iz svega vidljivo, književni karakter" (Šicel 1978: 23).

${ }^{4}$ Žmegač navodi paradigmatičan citat iz neobjavljena članka Milana Marjanovića iz 1914.: „Modernizam je bio negacija svakoga Creda, svake doktrine. U svojoj cjelini, on je rastrganost, trzavost, neskupljenost, dezorganizovanost. On je bio stanje duha, a ne pravac" (Žmegač 2001: 19; cf. 20).

${ }^{5}$ Književni kritičar i povjesničar Josip Bogner također piše: „Hrvatski modernisti prihvatiše, baš kao i ruski, češki i poljski, Nietzscheov individualizam, (...) i objesiše individualizam kao najvažniju kvalitetu na svoju modernističku firmu" (Bogner 1930: 169).

${ }^{6} \mathrm{O}$ utjecaju Nietzschea na naše moderniste cf. Staničić; ona među ostalim piše da je „Nietzsche pripadao u obaveznu lektiru generacije rođene sedamdesetih godina, pa su stoga bili izbliza izloženi mitu o prevrednovatelju moralnih i estetskih normi” (1991: 103). 
„temelji za tumačenje kulturnopovijesne europske moderne položeni su mahom u 18. stoljeću, a mogu se shvatiti kao četiri raznorodna očitovanja novovjekovnog individualizma" (Žmegač 2001: 11).

Razloga za sukob na kulturnoj sceni bilo je dakle mnogo - čekao se samo povod. Iskra je naposljetku planula nakon najave secesijske izložbe hrvatskih umjetnika 1898. Tada je muzikolog Franjo Ksaver Kuhač u svojoj prima furia složenoj ,poslanici umjetničkim secesionistima i dekadentima” Anarkija u hrvatskoj književnosti i umjetnosti žestoko prozvao „neke mladje hrvatske književnike” kao pripadnike urotničke struje koja ide „za tim, da našu mladež posvema pokvari, da joj iščupa iz srca smisao za moral, religiju, domoljublje i ina plemenita čuvstva i svojstva" (Kuhač 1898a: 3). On poziva mladež da ,ne ruši svetinje: moral, religiju i patriotične krieposti hrvatskoga naroda" te traži udruživanje svih književnih sila u jednu zadrugu, čiji smjer ,ne smije biti lažiliberalan i frivolan, nego k r š ć a n s k o moralan i h rvat s k o patriotičan" ([istaknuo F.K.K.] Kuhač 1898a: 25-26). Dakako, „mladi” su - među kojima su najistaknutiji Ivo Pilar, Branimir Livadić, Milivoj Dežman, Petar Skok i Milan Marjanović - odbacili Kuhačeve poruke, ponajprije zbog autorova ,policijskog” tona i njegove književne nekompetentnosti, osjećajući da on ,s gnušanjem i s indignacijom odbija mladu književnu generaciju"’7.

Rasprava se međutim rasplamsala nakon što je izašao članak Secesija Ive Pilara u „Viencu”. Članak je napisan ante festum prve izložbe hrvatskih secesionista i u povodu izlaska Hrvatskog Salona u prosincu 1898, u kojemu su Ksaver Šandor Gjalski i Milivoj Dežman svojim pledoajeom slobodi svjetonazora u umjetnosti zapravo iznijeli promemoriju modernističkih ideja i nastojanja u umjetnosti i književnosti ${ }^{8}$, dok je u svom članku Pilar ispisao svojevrsnu apologiju modernizmu. Opravdavajući nastojanje se-

${ }^{7}$ V. (Marjanović M.) 1898: 29-30. U istom broju „mladi” preporučuju čitateljima Pilarevu studiju Secesija; cf. Secesija 1898: 30-32.

${ }^{8}$ Gjalski je u nenaslovljenu tekstu pozvao umjetnike da se ne obaziru ni na kakve zahtjeve izvan sfera umjetnosti i opomene bilo kakvih ,škola”, zauzevši se za individualnost umjetničkog stvaranja (Gjalski 1898: 2), dok je Dežman Ivanov - naglasivši da mlade pisce vodi ljubav prema domovini i da štuju prinos starijih u razvoju hrvatske kulture te da mladi nipošto ne pristaju na to da se zatome „transcendentni porivi” - istaknuo da je mladima prije svega do toga da misle svojom glavom, pa makar i zlo, da izreknu svoje nazore, pa bili i krivi. „Slobode nam se hoće”, „ljudi slobodnih u duši svojoj”; (cf. Dežman-Ivanov 1898: 8-9). 
cesionista da se istrgnu iz čvrstog zagrljaja tradicije i dotadašnjih ,škola”, zauzeo se za umjetnost bez spona nacionalnih i političkih: „umjetnik mora imati apsolutnu umjetničku slobodu”, treba da iskazuje „,svu svoju dušu, sve ono, što osjeća, i baš onako, kako osjeća” (Pilar 1898: 572) jer treba „da se iskorijeni uvriježena zabluda, da je pojam «ljepote» nešto stalno i nepromjenljivo” (Pilar 1898: 590), istupivši protiv „sramotne dvoličnosti našega konvencionalnoga morala, protiv himbene svetosti" (Pilar 1898: $604)^{9}$. Misli Pilareve postale su idejno-duhovni program mladih ${ }^{10}$, a nosivi elementi bili su individualizam, kozmopolitizam i apsolutna sloboda stvaranja.

Nakon što je Pilar objavio svoje članke u organu Matice hrvatske „Viencu”, Kuhač se ponovno oglasio serijom članaka $O$ secesiji u „Hrvatskoj Domovini”, u kojima traži da se „mladi naši umjetnici i umjetnikovići” uzdignu do „hrvatskog umjetničkog patriotizma i do kršćanskog morala” (Kuhač 1898b: 259, 3). U „Viencu” je u obranu načela „starih” stao i pjesnik i filozof Franjo Marković, koji se kao „čovjek koji je hrvatsku književnost upućivao prema njezinim najvišim zadacima" (Barac 1938: 61) oborio na spomenuti Pilarov članak o secesiji, kao i na članke Dežmana i Gjalskoga u Hrvatskom Salonu. Marković veli da „pisac nema samo svojih prava nego ima i svojih dužnosti, prama obćinstvu i prama samomu sebi”, među kojima je i da „uči od starijih” (Marković 1899: 105, 121-122). U zaključku naglašava načelo da ,svaki čovjek, a navlastito umjetnik (...) ima težiti da postane što jasniji mikrokozam, što jasnije ogledalo makrokozma iliti individualni jav univerzalnosti, t. j. ogledalo i prikazivalo istine, ljepote i dobrote" (Marković 1899: 137), što je bilo načelo skolastičke filozofije.

Malo-pomalo rasprava o secesiji s općeumjetničkog gledišta sve se više sredotočila na književno pitanje ${ }^{11}$. U raspravu se umiješao i katolički tisak. U sarajevskoj „Vrhbosni” Ivan Šarić javio se raspravom Naturalizam u umjetnosti, zaključivši da izdvajanje umjetnosti iz prosudbe u ka-

\footnotetext{
${ }^{9}$ Istup protiv ,konvencionalnoga morala” Pilar ističe kao važnu značajku pokreta „,mladih" (Pilar 1903: 274).

${ }^{10}$ (Cf. Marjanović 1906: 13). Vladimir Lunaček datira početak hrvatske moderne u dan otvaranja „Prvog hrvatskog salona” 15. prosinca 1898 (Lunaček 1923: 505).

${ }^{11} \mathrm{O}$ uporabi pojma ,secesija” u hrvatskoj književnosti u to vrijeme (Žmegač 1992: 39$-55)$.
} 
tegorijama dobra i zla znači poživinčiti čovjeka (cf. Šarić 1898: 317) ${ }^{12}$. Zagrebački kanonik Stjepan Korenić naglašeno je polemizirao s izjavama Gjalskoga u „Hrvatskom Salonu” „ne obazirite se ni na kakove zahtjeve, što su izvan vaše umjetnosti” i „svatko neka svojim načinom daje”, optuživši ga da time želi umjetnost izdići iznad ikakvih načela i zakona (Korenić 1899: 16).

Bilo je dakako starijih pisaca koji su poduprli „mlade”. Osim Gjalskoga, kritičar Janko Ibler u režimskim je „Narodnim Novinama” nesmiljeno izrugao i sadržaj i nakanu i formu Kuhačeva „nezgrapnog pamfleta”, žaleći što je takva „papirnata bomba” uperena protiv cijele mlade književne generacije (cf. Ibler 1898: 3). Ne manje oštar bio je prvak Čiste stranke prava Josip Frank. Kuhač i ostali, piše Frank, ,propisuju umjetnosti stanovite ograničavajuće svrhe, oni joj propisuju šta se smije, šta ne smije raditi (...) oni zagovaraju cenzuru za umjetnost, te je upućuju na kazneni sud i na policajnu vlast" (Frank 1898: 23).

\section{Književnost sub specie aeternitatis}

Ali istupi „starih” nisu jenjavali. Poznati novinar i kritičar Dinko Politeo piše u „Viencu” članke pod naslovom Nekoje misli o književnosti na početku vieka s temeljnim zaključkom:

Budućnost literature ili literatura nije secesionizam: budućnost literatura absolutno je vjerska. (...) Nikada, ne nikada ne bih se umorio isticati, da ni secesionizam, ni druge škole, koje se u nas shvaćaju modernima, nisu moderne; ili barem nisu moderne u tom smislu, kao da bi prihvaćene bile od većine književnika. (...) Moderno je, ako tako mogu reći, vjersko pitanje; moderno je ono što je idealno; moderno je... ono, što je staro, ili ako se hoće, da budem točniji, povratak k starome (Politeo 1900: 156).

Polemika se intenzivirala kada je 1902. uredništvo „Vienca” preuzeo filozof i pjesnik i tada predsjednik Matice hrvatske Đuro Arnold. On je težište književničke borbe prenio na područje etike i religije. U svom čuvenom govoru na skupštini Matice hrvatske godine 1904. Književnost za cieli narod i njezina vrela ovako definira svoje temeljno polazište:

${ }^{12} \mathrm{U}$ tom duhu tih su godina o naturalizmu pisali svi katolički kritičari, pisci i apologeti. 
Umjetnost, koja se nikada ni na što ne osvrće, koja je dakle skroz formalna, može u najpovoljnijem slučaju biti l'art pour l'artistes, nikada pak l'art pour le nation, jer joj je uviek osnovan egoizam - ako i decentralizovan. S rečenog socijalnog gledišta trebat će prosudjivati i snošaj umjetnosti prema moralu. Da bi umjetnici imali pravo na poseban moral, ne će valjda nitko ozbiljno tvrditi, jer nije pojmljivo, zašto slično pravo ne bi onda pripalo i drugim zvanjima. (...) To pak drugim riečima znači: mi ne možemo nikako lučiti umjetnika od čovjeka, jer to i nisu dva lica. (...) Slično je sa snošajem umjetnika prema vjeri. Često se, istina, čuje da je vjera privatna stvar pojedinca, ali to vriedi tek s egoističkog, ograničenog, uobraženog gledišta, koje pojedinca smatra zasebnim svietom. S gledišta socijalnog ili narodnog ima se stvar drugojačije. Pošto nema naroda bez vjere, to s njom mora svaki pojedinac računati - ako ne će da znači negaciju jednoga narodnog ideala. Pogotovo pak mora da s njom računaju umjetnici i pjesnici, jer im bez vjere ne dostaje jasnoće u zadnjim pitanjima života, slobode i svjetskoga poredka - a potom bitnoga uvjeta estetske harmonije. (...) Uzme li se k tomu, da je živa vjera najjači bedem protiv materijalizma i pesimizma i da ono po izkustvu najviše čuva i podiže, vodi i poljepšava život - onda je jamačno i za sliepca, da književnosti, koja je namienjena cielom narodu, ne može biti bez vjere (Arnold 1904: 1).

Modernisti žestoko reagiraju na taj govor. Arnoldu u „Pokretu - glasilu hrvatskih naprednjaka"13, radikalno obojenu ,antiklerikalizmom”, odgovara Branimir Livadić, među ostalim osvrnuvši se i na pitanje odnosa između književnosti, vjere i morala. Livadić drži da „netko može biti u tom smislu pravi bezvjerac, a imati duboko religijozno čuvstvo", primjerice Nietzsche, pa Arnoldov govor u tom pogledu drži nejasnim i nedorečenim (cf. Livadić 1904: 2). S obzirom na moral, misli da se on može usavršavati te da ga nipošto ne treba vezivati s Crkvom, uzevši kao primjer Tolstoja, koji je ekskomuniciran iz Ruske pravoslavne crkve, ali je daleko od toga da ga se proglasi nemoralnim (cf. Livadić 1904: 2). Arnold je međutim slične govore održao i sljedećih godina, osuđujući larpurlartizam i braneći skolastičko načelo jedinstva istine, dobrote i ljepote ${ }^{14}$.

${ }^{13}$ U to vrijeme „Pokret”, koji je napao Arnolda, i katolički usmjereno „Hrvatstvo”, osnovani iste godine, uđoše u nesmiljenu višegodišnju polemiku. Većeslav Wilder, jedan od istaknutih ,,pokretaša”, najžešćim se riječima oborio na „crnu aždaju” - „klerikalizam”, navijestivši mu „neminovnu i otvorenu borbu” (Wilder 1904: 1). Istupom protiv Arnolda ideološku palicu modernizma preuzimaju u to vrijeme njegov najborbeniji ideolog ,mladih" Branimir Livadić, a zatim Milan Marjanović, njegov najustrajniji tumač i publikator.

${ }^{14} \mathrm{U}$ govoru 1905. Umjetnost prema znanosti zauzima se da umjetnost ide po zlatnoj srijedi između ,idealnoga realizma ili realnoga idealizma” (Arnold 1906: 5). Govor na Matičinoj skupštini godine 1908. posvetio je odnosu između umjetnosti i vjere. Istaknuvši njihovu suprožetost, Arnold međutim upozorava na to da „blaženstvo” koju daje umjetnost nipošto nije „blaženstvo” koju daje kršćanska vjera (1908: 53-55). 


\section{Modernizam kao antiklerikalizam}

„Repovi” tih sukoba vukli su se i sljedećih godina. Među „starima" u tome je smislu bio najagilniji Jovan Hranilović (Hranilović 1905; 1906abcd). Pridružuju mu se Kerubin Šegvić (cf. 1906; 1907), a Albert Bazala ${ }^{15}$ i Vjekoslav Klaić (1906: 33-34) ${ }^{16}$ uključuju se filozofijskom razradbom, osudivši individualizam i larpurlartizam te, s druge strane, braneći idealizam i ulogu religije u umjetnosti. Livadić će pak, najborbeniji među modernistima, nakon što je 1907. postao urednik, „Savremenika”, časopisa Društva hrvatskih književnika, vrlo oštro ući u polemiku s najborbenijim među „starima” Jovanom Hranilovićem (Livadić 1907: 2-3). Dok je njega zaokupljala književna sloboda, Milan Marjanović je bio književni pragmatik, ideolog i propagandist modernizma. Za nj je književnost sredstvo idejne i političke borbe, osobito protiv klerikalizma (Barac 1938: 237; cf. Marjanovič 1908: 472) $)^{17}$.

Dakako, nezaobilazan je u svemu tome bio Antun Gustav Matoš. Protivan Marjanovićevu jugoslavizmu i kritičan prema „modernistima”"18, kojima se znao i narugati, Matoš je na svoj način također stajao na modernističkim načelima književnosti što ih je promovirao „Savremenik” pod geslom „slobode stvaranja bez spona”. Rano, već nakon njegova članka o Voltaireu Pismo iz Ferneya, snažno ga je napao „Katolički list” (cf. [b.a.] 1898: 412-414). Premda je 1914. umro kao katolik, Matoš je naime

${ }^{15}$ Sažetak tih pogleda u: Bazala (1906). Uz ostalo, Bazala kaže da se ,principijelno mora dopustiti, da će se u umjetnosti očitovati i religijske vrijednosti, da će one umjetnički dojam polučiti onda, ako se slažu s religijskim ćućenjem uživalaca ili mu se bar ne protive, ne vrijedjaju ga. To je uvjet, koji izvire iz prirode umjetnosti” (1906: 157).

${ }^{16}$ Zanimljivo je da Klaić estetske formaliste naziva ,idealisti”; „realisti” su oni koji traže da književnost služi pouci, dok su „modernisti” larpurlartisti. Klaić zaključuje da ,imade lijepa knjiga ne samo prava, nego i dužnosti" prema čovječanstvu i prema Hrvatskoj i njezinoj kulturi, pa stoga ,lijepa knjiga mora biti i tendencijozna, plemenito tendencijozna. A tendencija mora biti pozitivna: iz najdubljega taloga zla mora izvaditi bar zrnce dobra, u truležu i smrti mora tražiti i naći prve klice novoga života" (Klaić 1906: 34).

${ }^{17}$ Marjanović piše da klerikalizam ,hoće da zavlada cjelokupnim privatnim i javnim, vanjskim i nutarnjim životom čovjeka”, zaključivši da je klerikalizam danas u Hrvatskoj ,neprispodobivo jači i organizovaniji, radiniji i promišljeniji od antiklerikalizama" (Marjanović 1908: 477), čemu je potreban otpor, odnosno sekularizacija kulture i društva.

${ }_{18}$ „Moj modernizam nije modernizam Milana Šarića, Plavšića, Tauska, Šmida-Jugovića, dra. Korporića, Vl. Jelovšeka, Mil. Dežmana i M. Marjanovića” (Matoš 1907: 75). 
neprestance bio u sukobu s katoličkom inteligencijom, osobito s piscima svećenicima, pa nije neobično kad u polemici s Hranilovićem naglašava da

i jeste jedna od najnesrećnijih anomalija naše literarne kritike, što su tu do najnovijeg vremena davali ton svećenici, gg. dr. Čuka, Šegvić, Hranilović, Korenić itd. Kod nas nikako ne mogahu zbog najsuprotnijih načela i temperamenata, karakterizirati t. zv. modernu struju, jer ne opaziše, da nas najviše razlikuje od Starih uvjerenje, da umjetničko djelo može biti liepo i u sasvim nekršćanskom duhu, što više: da umjetnost može, ali ne mora biti etična i moralna ${ }^{19}$. Time ne negiram etične i religijozne uzore naše starije književnosti. Ne. Tražeći od umjetnine ponajprije da bude liepa, da bude potenciran život bio on religiozan, moralan ili instinktivan, bezvjerski i nemoralan, naš modernizam je promienio gledište naše starije etičke estetike, sputane religijom, razširivši joj horizonat i pruživši umjetničkom stvaranju više slobode. Dok je ciela naša starija književnost katolička i etička, hrvatski modernizam je u svom jezgru estetičan i antiklerikalan i to mu je glavno obilježje (Matoš 1906: 1).

I to je idejni ključ modernizma - antiklerikalizam. Iako politički antipodi, Matoš i Marjanović konvergiraju u mišljenju o antiklerikalizmu kao glavnom obilježju modernizma, iz čega je jasno da su ga u cjelini modernisti smatrali „,bitnim”, supstancijalnim obilježjem moderne. To potvrđuje zaključak Vladimira Lunačeka, koji 1923. u svojoj Bilansi hrvatske moderne zaključuje:

Moderni su većinom u prvome redu bili antiklerikalni (...) Doduše je baš na ovome području moderna morala najprije kapitulirati. Tu je doživjela poraz kao ni na jednom području prije ili kasnije. Protiv modernog antiklerikalizma digla se klerikalna katolička organizacija. Precjenjivali su se moderni kad su mislili, da će srušiti katoličku crkvu. Ta čitava ekskurzija o antiklerikalizmu bila je zato nužna, da se iznese, jer su moderni mislili da su kler i kršćanstvo krivi dekadensi u umjetnosti i u književnosti koli u svijetu tako i kod nas (Lunaček 1923: 512-513).

Premda Lunaček pretjeruje kad tvrdi da su hrvatski modernisti htjeli srušiti Katoličku crkvu, citat opravdano ističe kako se među modernistima

${ }^{19} \mathrm{U}$ polemici s Marjanovićem Matoš ističe misao francuskih artista da „sve ideje mogu služiti umjetnosti, dok ona ne smije robovati ni jednoj, pa bila ona i etična” te da je ,čisti artist aristokrat, individualist, indiferentan u moralnim pitanjima...” (Matoš 1911: 358-359). Na tu Matoševu izjavu reagirao je u „Vrhbosni” fra Ignacij Radić u članku Estetika kao uzgojni faktor, gdje, dopuštajući da je glavni cilj umjetnosti estetičan, ističe da je ,ideja estetična podložna etičnoj, a ne obratno” jer je estetika „ljudsko čuvstvovanje ili djelovanje, a svako je ljudsko djelovanje podložno etici”; , prava umjetnost preobrazuje, razvija i usavršava naš razum, volju i čuvstva; ona nas uzdiže i oplemenjuje; baš zato ljepota i s njome skopčana umjetnost imade ne samo estetsku već i neku pedagošku i etičku vrijednost” (Radić 1912: 21). 
ustrajno gajio antiklerikalizam kao „sinekvanon”, kako reče Krleža ${ }^{20}$, koji se gdjekad pretvarao i u stanoviti odium Ecclesiae, pa i u odium christianitatis, ako već nije i u odium fidei.

\section{Zaključak}

Podložna dakle kojekakvim ekstravagancijama i pretjeranostima „mladih”, koji su „u svom modernizmu često išli do pravoga apsurda i shvaćali individualizam kao negaciju svakoga zakona i potpuni anarhizam", stvarajući više histeričnu, nervoznu i fragmentarnu literaturu nego ozbiljnu, sustavnu i sređenu, moderna je, pisao je književni kritičar i povjesničar Josip Bogner, „nužno morala da izazove sukob s konzervativnim Starima” (Bogner 1929: 329) ${ }^{21}$. Slično na drugome mjestu ustvrđuje da je moderna, započevši, „kao što je posve normalno, kriticizmom”, zapala, „što je sasvim abnormalno, (...) u neodređenost, afektaciju, kaprice i ekstremnosti" (Bogner 1930: 161-162), shvativši i samu slobodu kao moralnu anarhiju (cf. Bogner 1930: 170). To priznaju i sami modernisti. Marjanović, analitik hrvatskoga književnoga realizma i moderne, liberalni integrist, daleko od kršćanskoga gledanja, konstatira da su književnici ,zapali u sve veći sentimentalizam, fatalizam i pesimizam" (Marjanović 1906: 13), jer je naša književnost bila lišena ,filozofske baze” (cf. Marjanović 1906: 14). Točno, ali ne kaže koje baze. Istina je da je hrvatska književnost tada bila sve više lišavana - kršćanske filozofijske baze. „Tema religije i kršćanstva”, kako će se slikovito izraziti Zoran Kravar, bijaše „najveća kost u grlu modernističkoga životnog osjećaja i njegove filozofije" (Kravar 2001: 226). I Pilar je 1903. uvidio da uzorima „mladih” Gjalskome i Kozarcu „manjka svaki harmonički nazor o svijetu, a pogotovo neko ustaljeno filozofsko uvjerenje” (Pilar 1903: 260), čemu je uzrok to što „nam sasvijem manjka razvitak,

${ }^{20}$ „da se je smelo da napiše da muž sa ženom spava u postelji gol. I to je bio jedan od kardinalnih 'sinekvanonova' našeg literarnog libertinskog stvaranja. To se je zvalo seksualno pitanje, a drugi sinekvanon bio je antiklerikalizam” (Krleža 1921: 539).

${ }^{21}$ „Moderna je de facto proizašla iz težnje omladine, da stariju jednostranost zamijeni modernom svestranošću - i da je na tom terenu ostala, hrvatska Moderna ne bi završila pretjeranim i abnormalnim ekstravagancijama (,Sinfonije” V1. Jelovšeka i sl.), dotično nepotrebnim i neprincipijelnim borbama Starih i Mladih" (Bogner 1930: 161). 
bolje reći preporod filozofsko-etični” (Pilar 1903: 261). Tako Pilar, koji je svojim člankom o secesiji svojedobno pripalio stijenj književničke polemike, sad ističe „napadnu besciljnost”, ,izvanrednu dezorijentaciju” i „manjak čvrstih točaka” „mladih” (cf. Pilar 1903: 260). Drugim riječima, kako će poslije konstatirati Bogner: „Hrvatskoj je Modernoj nedostajala idejna fundiranost i programatičnost. (...) Nemajući svoga vlastita nazora o svijet, sistematske filozofske baze, Mladi su se sasvim grčevito hvatali svake ideje, samo da zatrpaju svoju prazninu" (Bogner 1930: 162)22. Imajući na umu te značajke, u vjerskom pogledu modernistički pisci, premda se većina nije odrekla Boga, pa ni Crkve, redovito jesu dvojili o naravi i praktičnom dometu svoje vjere, a svoju su umjetnost izdvojili iz moralno-vjerskog nauka i nadzora Crkve, koju su dapače držali organizacijom koja onemogućuje slobodu umjetnosti. No tako shvaćena sloboda vodila je moderniste u slijepu ulicu inidvidualizma, koji se, eo ipso, morao zaogrnuti antitradicionalizmom.

Valja ipak reći da unatoč antikatoličkim, posebice anticrkvenim invektivama i „ekscesima laicizma” (cf. Bogdan 1959: 139), hrvatska književna moderna u cjelini nije bila organizirani antikršćanski ili antikatolički pokret. Ne može se međutim poreći da su hrvatski modernisti katolicizam javno angažiran za promicanje kršćanskih načela u društvu shvaćali kao klerikalizam: jednako ideolozi moderne, primjerice Marjanović i Livadić, kao i beletristi, primjerice Gjalski i Matoš, ili kritički mentori „mladih”, primjerice Ibler $^{23}$. Njima je bio prihvatljiv samo liberalni katolicizam, katolicizam prilagodljiv modernističkoj misli, oslobođen od autoriteta Učiteljstva Crkve. Smatrajući se slobodoumnima, smatrali da se katolicizam mora prilagoditi modernom subjektivizmu, relativizmu i pragmatizmu želi li uopće opstati, a Crkva se nipošto ne smije miješati u javne poslove. Stoga je njihov antiklerikalizam u velikoj mjeri poprimao obrise otpora javnom očitovanju katolicizma u kulturi, navijestivši tako sekularističke idejne procese koji će se poslije očitovati u političkom i svekolikom društvenom životu. A to će uvelike odrediti razvoj hrvatske književnosti sljedećih desetljeća, počevši s Krležom, koji u godini Matoševe smrti i kraja

${ }^{22}$ O tome već (Marjanović 1902: 183).

${ }^{23}$ Ibler u povodu napada „Katoličkoga lista” na ,Vienac” 1903. piše da se književnost „,ne može skučiti pod vlast klerikalnih cenzora, (...) koji u svojoj zasukanosti misle, da su u monopol uzeli pojam umjetničke ljepote" (Ibler 1903: 296, 4). 
moderne svojim Legendama snažnije nego itko prije želi hrvatsku književnost preusmjeriti iz njezine tradicijske, kršćanske duhovne matice. Tako je i književnost postala sredstvo promjene hrvatskoga tradicionalnoga duhovnog koda, koji je od početka hrvatske poznate povijesti bilo odredilo i oblikovalo kršćanstvo.

Zaključno, iako su „stari” solidno branili načela kršćanske philosophiae perennis, „mladi” su agresivnošću i, naposljetku, zahvaljujući biološkim zakonima, nadvladali. Na tu „pobjedu” odgovorit će organizirano nova elita katoličke inteligencije što ju je iznjedrio Hrvatski katolički pokret $^{24}$, koji će organizacijski oblikovati krčki biskup Antun Mahnić25, u sklopu kojega će se pod književnoprogramskim vodstvom Ljubomira Marakovića (o njemu cf. Lončarević 2003) razviti hrvatska katolička književnost kao moderni književnički odgovor katolika na modernizam (o tome cf. Lončarević 2005).

\section{Literatura}

Arnold Gj., 1904, Govor 16. 10. 1904. na Skupštini Matice hrvatske, „Hrvatstvo” br. 140 , str. $1-2$.

Arnold Gj., 1906, Umjetnost prema znanosti, „Glas Matice Hrvatske” br. 1-2, str. 2-5. Arnold Gj., 1908, Može li umjetnost zamijeniti vjeru, „Glas Matice Hrvatske” br. 6, str. 41-43; br. 7, str. 53-55.

Barac A., 1938, Hrvatska književna kritika, Zagreb.

Bazala A., 1906, O umjetnosti, „Glas Matice Hrvatske” br. 13-16, str. 121-129; br. $17 / 20$, str. $149-158$.

Bogdan I., 1959, Baština Ljubomira Marakovića (7. VI. 1887.-21. II. 1959.), „Hrvatska revija" br. 2 (34), str. 136-145.

Bogner J., 1929, Pokreti i struje u hrvatskoj i srpskoj književnosti od moderne do nadrealizma, [disertacija, strojopis], Arhiv Filozofskoga fakulteta u Zagrebu.

Bogner J., 1930, Hrvatska moderna, „Književnik” br. 4, str. 159-172.

Bozanić A., 2010, Biskup Antun Mahnić i Hrvatski katolički pokret-inicijative i ostvarenja u hrvatskom javnom životu, „Riječki teološki časopis” br. 2, str. 511-532.

Dežman-Ivanov M., 1898, Naše težnje, „Hrvatski salon” sv. 3, str. 8-9. Flaker V., 1977, Časopisi hrvatskog modernističkog pokreta, Zagreb. Frangeš I., 1987, Povijest hrvatske književnosti, Zagreb-Ljubljana.

${ }^{24}$ Iz obilja literature o Hrvatskom katoličkom pokretu preporučujem konzultirati: Matijevič 2002; Krišto 2004.

${ }^{25} \mathrm{O}$ njegovoj ulozi u razvoju Hrvatskoga katoličkog pokreta cf. Bozanić 2010. 
Frank J., 1898, U obranu hrvatskih umjetnika. Odgovor F. Kuhaču, Zagreb.

Gjalski K.Š., 1898, „,Pozvan od prijatelja... ”, „Hrvatski salon” sv. 3, str. 1-2.

Hinković H., 1902, Modernizam u liepoj knjizi. Misli i dojmovi, Zagreb, str. 1-17.

Hranilović J., 1905, Osvrt na hrvatsku beletristiku od godine 1900. do najnovijeg vremena, „Hrvatsko kolo” b.b., str. 337-374.

Hranilović J., 1906a, „Mladi” u hrvatskoj književnosti, „Glas Matice Hrvatske” br. 1-2, str. 9-10; br. 3-4, str. 25-26.

Hranilović J., 1906b, Logika branitelja modernizma, „Glas Matice Hrvatske” br. 10, str. $84-87$.

Hranilović J., 1906c, Savremeniku, „Glas Matice Hrvatske” br. 7, cit. prema: Nekrolog hrvatskoj modernoj. Polemike u hrvatskoj književnosti, 1983, ur. I. Krtalić, Kolo II - knjiga VIII, Zagreb.

Hranilović J., 1906d, Tumač i branitelj hrvatske moderne, „Glas Matice Hrvatske” br. 5-6, str. 37-38; br. 7, str. 54-55.

Ibler J., 1898, Anarhija u hrv. književnosti i umjetnosti, „Narodne novine” br. 180, str. $1-3$

Ibler J., 1903, Matica Hrvatska i ,Vienac”, „Narodne novine” br. 295, str. 4-5; br. 296, str. 3-4; br. 297 , str. 3.

Klaić V., 1906, Čemu nam lijepa knjiga?, „Glas Matice Hrvatske” br. 5-6, str. 33-34.

Korenić S., 1899, Nekoliko misli k našemu umjetno literarnom pokretu, Zagreb.

Kravar Z., 2001, Svjetonazorski separei, u: N. Batušić, Z. Kravar, V. Žmegač, Književni protusvjetovi. Poglavlja iz hrvatske moderne, Zagreb, str. 221-229.

Krišto J., 2004, Hrvatski katolički pokret 1903.-1945., Zagreb.

Krleža M., 1921, Ljudi od papira, odlomci staromodne pripovesti iz vremena kada je umirala Hrvatska Moderna, „Nova Evropa” br. 14, knj. 2, str. 537-549.

Kuhač, F.Š., 1898a, Anarkija u hrvatskoj književnosti i umjetnosti. Poslanica umjetničkim secesionistima i književnim dekadentima, Zagreb.

Kuhač F.Š., 1898b, O secesiji, „Hrvatska Domovina” br. 255, str. 1-2; br. 256, str. 2-3; br. 257 , str. 3 ; br. 258 , str. $3-4$; br. 259 , str. 3 .

Livadić B., 1904, Književnost i njezini ciljevi, „Pokret” br. 30, str. 1-2.

Livadić B., 1907, Jovan Hranilović na braniku , starih”, „Pokret” br. 57, str. 2-3.

Lončarević V., 2003, Luči Ljubomira Marakovića, Zagreb.

Lončarević V., 2005, Književnost i Hrvatski katolički pokret, Zagreb.

Lunaček V., 1923, Bilanca hrvatske moderne, ,Savremenik” br. 9, str. 505-513.

Maraković Lj., 1943, Od preporoda do danas u: Naša domovina. Zbornik, ur. F. Lukas, knj. I, sv. II, Hrvatska kultura - politička povijest Hrvata, XVII, Hrvatska književnost, Zagreb, str. 639-646.

Marjanović M., 1902, Naša moderna beletristika, „Hrvatska misao” br. 6, str. 177-183.

Marjanović M., 1906, Iza Šenoe. Drugi dio. (Od 1894.-1904), Svačić, hrvatski ilustrovani koledar, str. 13-36.

Marjanović M., 1908, Klerikalizam, „Zvono” br. 29-30, str. 469-480.

Marković F., 1899, Predavanje o izložbi ,,družtva hrvatskih umjetnika”, „Vienac” br 7, str. 104-106; br. 8, str. 121-123; br. 9, str. 137-138. 
Matijević Z. (ur.), 2002, Hrvatski katolički pokret, Zagreb.

Matoš A.G., 1906, Kritika gosp. Jovana Hranilovića , „Novi list” br. 34, str. 1.

Matoš A.G., 1907, Sintetična kritika, „Hrvatska smotra” b.b., str. 20-27; 73-80.

Matoš A.G., 1911, Realizam i artizam, „Savremenik” br. 6, str. 356-361.

Milanja C., 1987, Janko Leskovar, Zagreb.

Petrač B., 1995, Duhovne odrednice hrvatske književnosti, „Croatica Christiana Periodica" br, 36, str. 77-95.

Pilar I., 1898, Secesija, „Vienac” br. 35, str. 540-541; br. 36, str. 555-557; br. 37, str. $570-573,575$; br. 38 , str. 590-591; br. 39, str. 603-605.

Pilar I., 1903, Zagrebački literarni pokret, „Nada” br. 16, str. 214-216; br. 17, str. 230-231; br. 18, str. 245-246; br. 19, str. 260-261; br. 20, str. 273-275; br. 21, str. 286-287.

[b.a.] „Pismo iz Ferneya” ili: kamo ćemo jošte u Hrvatskoj doći?, 1908, „Katolički list" br. 51, str. 412-414.

Politeo D., 1900, Nekoje misli o književnosti na početku vieka, ,Vienac” br. 10, str. 155-156; br. 11, 170-171.

Radić I., 1912, Estetika kao uzgojni faktor, „Vrhbosna” br. 2, str. 19-22; br. 3, str. 33-36.

Secesija, 1898, „Nova Nada” br. 1, str. 30-32.

Šarić I., 1898, Naturalizam u umjetnosti, ,Vrhbosna” br. 20, str. 314-317.

Šegvić Ch., 1906, Sloboda stvaranja, „Glas Matice Hrvatske” br. 11, str. 97-102.

Šegvić K., 1907, Moralna odgovornost knjige, „Glas Matice Hrvatske” br. 7-8, str. 56-57; br. 9-12, str. 66-67.

Šicel M., 1978, Povijest hrvatske književnosti. Moderna, sv. 5., Zagreb.

Šicel M., 2002, Janko Leskovar - začetnik proze hrvatske moderne, „Hrvatsko zagorje” br. 1 , str. $81-84$.

Staničić M., 1991, Friedrich Nietzsche i hrvatska moderna, „Croatica” br 35-36, str. 101-117.

Ujević M., 1933, Prilozi za povijest pokreta hrvatske omladine koncem XIX i početkom XX stoljeća, s osobitim osvrtom na borbu starih i mladih, [strojopis], NSK, Obiteljski arhiv, RB: I.

V. (Marjanović M.), 1898, Anarhija u hrvatskoj književnosti i kulturi, „Nova Nada” br. 1, str. 29-32.

Wilder V., 1904, Klerikalizam, „Pokret” br. 37, str. 1.

Zdziechowski M., 1903, Pjesništvo poljsko i preporod Hrvatske, „Obzor” br. 102, str. 1; br. 103, str. 1; br. 104, str. 1-2.

Žmegač V., 1992, Secesija i hrvatska književnost oko 1900, „Umjetnost riječi” br. 1, str. 23-56.

Žmegač V., 2001. Osnove moderne, u: N. Batušić, Z. Kravar, V. Žmegač, Književni protusvjetovi. Poglavlja iz hrvatske moderne, Zagreb, str. 11-24. 